\title{
Evaluation of Spot Urinary Calcium to Creatinine Ratio in Preeclampsia: A Cross Sectional Comparative Study
}

\author{
Hasina Begum¹, Md. Nazibur Rahman², Menoka Ferdous³, Sankar Kumar Basak4, \\ Nilufar Yasmin ${ }^{5}$, Ayesha Parveen ${ }^{6}$ \\ ${ }^{1}$ Junior Consultant, Department of Obstetrics \& Gynaecology, Shaheed Suhrawardy Medical College \& Hospital, \\ Dhaka, Bangladesh; ${ }^{2}$ Assistant Professor, Department of Pathology, Dhaka Medical College, Dhaka, \\ Bangladesh; ${ }^{3}$ Assistant Professor, Department of Obstetrics \& Gynaecology, Shaheed Suhrawardy Medical \\ College, Dhaka, Bangladesh; ${ }^{4}$ Junior Consultant (Obstetrics \& Gynaecology), District Sadar Hospital, \\ Feni, Bangladesh; ${ }^{5}$ Assistant Professor, Department of Obstetrics \& Gynaecology, Shaheed \\ Suhrawardy Medical College, Dhaka, Bangladesh; ${ }^{6}$ Junior Consultant, Department of \\ Obstetrics \& Gynaecology, Shaheed Suhrawardy Medical College \& Hospital, Dhaka, \\ Bangladesh
}

[Received: 21 January 2016; Revised: 6 March 2016; Accepted: 11 December 2016; Published: 1 January 2017]

\begin{abstract}
Background: Preeclampsia (PE) is a pregnancy related condition leading to significant mortality and morbidity. A number of renal changes are seen in preeclampsia. Objectives: This study was designed to determine the association of calcium to creatinine ratio in a spot sample of urine with preeclampsia. Methodology: This cross-sectional comparative study was conducted in the Obstetrics \& Gynaecology department of Dhaka Medical College, Dhaka, Bangladesh. Pregnant women with preeclampsia without complication and women with normal pregnancy without complications were selected for the study. Calcium, creatinine, Protein and calcium to creatinine ratio was measured in a spot urine sample of all these 150 subjects. Blood was also collected from all the cases for measurement of serum calcium, creatinine and uric acid. Results: A total of 150 pregnant women, 75 with preeclampsia without complication and 75 with normal pregnancy without complications were selected for the study. Significant difference between PE and normal group was observed in case of mean serum calcium and uric acid concentration but mean serum creatinine did not vary significantly. Urinary creatinine concentration did not show any significant difference. But mean urinary calcium concentration in spot sample of urine was significantly lower in preeclampsia than normal pregnant woman $(3.45 \pm 2.61 \mathrm{mg} / \mathrm{dl}$ vs $7.39 \pm 2.80 \mathrm{mg} / \mathrm{dl}, \mathrm{p}<0.001)$. Similarly mean calcium to creatinine ratio in spot sample of urine was significantly lower in the pre-eclampsia than normal group $(0.06$ \pm 0.05 vs $0.13 \pm 0.06, p<0.001)$. Positive correlation was observed between urinary calcium/creatinine ratio and urinary calcium $(\mathrm{r}=+0.68, \mathrm{p}<0.001)$ but negative correlation $(\mathrm{r}=-0.39, \mathrm{p}<0.001)$ noted between urinary calcium/creatinine and urinary protein. Conclusion: Spot urinary calcium and creatinine ratio decreases in preeclampsia. So spot urinary calcium and creatinine ratio can be regarded as a predictor for preeclampsia. [Journal of National Institute of Neurosciences Bangladesh, 2017;3(1): 14-20]
\end{abstract}

\section{Keywords: Preeclampsia; Spot; Urinary Calcium; Creatinine Ratio}

Correspondence: Correspondence: Md. Nazibur Rahman, Junior consultant, Obs \& Gynae, Shahid Suhrawardy Medical College \& Hospital, Sher-E-Bangla Nagar, Dhaka, Bangladesh. Email: hasina.lipi6@gmail.com; Cell No.: +8801711050004

Conflict of Interest: The authors declare that they have no competing interest.

Contributions to Authors: HB, MF, NF were involved in protocol preparation, data collection and data analysis. HB, AP, MNR were contributed for the manuscript preparation SKB \& MNR were revised the manuscript.

Funding: This research project was not funded by any group or any institute on.

How to cite this article: Begum H, Rahman MN, Ferdous M, Basak SK, Yasmin N, Parveen A. Evaluation of Spot Urinary Calcium to Creatinine Ratio in Preeclampsia: A Cross Sectional Comparative Study. J Natl Inst Neurosci Bangladesh, 2017;3(1): 14-20

Copyright: (C2017 Begum et al. Published by Journal of National Institute of Neurosciences Bangladesh. This article is published under the Creative Commons CC BY-NC License (https://creativecommons.org/licenses/by-nc/4.0/). This license permits use, distribution and reproduction in any medium, provided the original work is properly cited, and is not used for commercial purposes.

\section{Introduction}

Pre-eclampsia (PE) is a pregnancy specific condition characterized by hypertension and proteinuria occurring after 20 weeks of gestation and complicates about 8 to $10 \%$ of pregnancies ${ }^{1}$. It is a serious complication of second half of pregnancy and leading cause of foetal 
growth retardation, perinatal and maternal mortility and morbidity. All over the world PE is 3rd and 7th leading cause of maternal and perinatal mortility and morbidity respectively and $16.0 \%$ of all maternal death in UK. In developing countries Preeclampsia effect $4.4 \%$ of all deliveries and may be as high as $18 \%$ in some areas in Africa $^{2}$. In Bangladesh it is about $10 \%$ of all deliveries ${ }^{3}$. PE is a multistage disease characterized by abnormal placental development leading to endothelial dysfunction and damage. There is a failure of trophoblast remodeling of uterine spiral arteries resulting in sclerotic narrowing of blood vessels, increased vascular resistance and mechanical constriction which ultimately produce placental eschaemia and infarct. This lead to release of excessive amount of secreted factor into maternal circulation producing clinical signs and symptoms of preeclampsia. The pathological lesion in utero-placental bed is necrotizing arteriopathy leading to reduced placental perfusion. In severe disease there is widespread organ dysfunction specially kidney, liver and brain. But chief target organ in kidney; hence proteinuria and hypertension are the predominant clinical features ${ }^{4,5,6,7}$.

In healthy pregnant women marked glomerular hyperfiltration (IGFR ) is seen above normal nongravid level by 40 to $60 \%$ primarily due to reduced plasma oncotic pressure (RPF) in glomerular capillaries, hypovolumia induced haemodilution and elevated rate of renal plasma flow (RPF) . But in PE there is variable degree of renal insufficiency and GFR and RPF both are significantly reduced ${ }^{8}$. One of the most important clinical problems is that pre-eclampsia and complications appear suddenly in pregnant women and unfortunately as yet no definite predictive factor is available. Several potential predictive associated factors have been proposed for preeclampsia which include markers for liver and renal function (creatinine, uric acid, ALT, AST), vascular function (thromboxane, prostaglandin, nitric oxide, cytokines, LDH), coagulation and fibrinolytic factor (platelets, fibrinogen, antithrombin 3, plasminogen activator), oxidative stress and lipid (lipoprotein, lipid peroxide, antioxidant), placental function (HCG, placental growth factor, $\alpha$-FP, inhibin), calcium and calcium/creatinine ratio ${ }^{9-10}$. Calcium metabolism is characterized by changes during pregnancy. Calcium metabolism increases in all pregnant women possibly because of increased intestinal absorption of calcium, increased renal filtered load of calcium and increased GFR of pregnancy ${ }^{11-12}$. Several abnormalities of calcium metabolism has been described in preeclampsia most important being hypocalciuria i.e. reduced renal calcium excretion. It is possibly due to reduced dietary intake of calcium, decreased absorption, increased uptake by foetus and placenta, reduced GFR, increased glomerular calcium reabsorption ${ }^{13,14,15}$

Conventionally, 24hrs urine is required to assess hypocalciuria which is cumbersome, subject to collection error, require good patient compliance and more than $24 \mathrm{hrs}$ delay in diagnosis. So patient management is delayed. Several studies revealed that spot urinary calcium/creatinine ratio is a good indicator of urinary calcium excretion (hypocalciuria) and correlates well with $24 \mathrm{hrs}$ calcium excretion ${ }^{16}$. So estimation of spot/random urine calcium/creatinine ratio could be a simpler, quicker, more convenient and less expensive test to assess and predict pre-eclampsia. Several investigators studied spot urinary $\mathrm{Ca} / \mathrm{Cr}$ ratio in $\mathrm{PE}$ and it was found to be reduced ${ }^{1,17,18,19}$. All of them suggested that spot urinary $\mathrm{Ca} / \mathrm{Cr}$ ratio could be a predictive factor for pre-eclampsia. But there are some negative results also ${ }^{20,21,22,23}$. Inspite of these controversies several results are very promising ${ }^{24,25,26}$. No such work has been undertaken in Bangladesh before. So this study was done with Bangladeshi subjects to evaluate the association between spot urinary calcium and creatinine ratio and pre-eclampsia as it was required an specific, low cost, easy and quicker test to predict pre-eclampsia.

\section{Methodology}

This cross sectional comparative study was done in the Obs \& Gynae department of Dhaka Medical College Hospital involving two years. A total of 150 patients, all pregnant women (75 normal pregnant and 75 with pre-eclampsia) were taken by purposive non-random sampling. Patients attending the OPD at second half of gestation and admitted into the indoor of Dhaka Medical College Hospital were the study population. The cases were selected according to inclusion and exclusion criteria and were divided into two groups-a) Group I; Patients with pre-eclampsia \& B) Group II; Normal pregnant woman. Inclusion criteria for group I were-i) Pregnant woman with pre-eclampsia with gestational age between 24-40weeks (age 18-35yrs), ii) Diastolic blood pressure $\geq 90 \mathrm{~mm} \mathrm{Hg}$ and Systolic blood pressure $\geq 140 \mathrm{~mm} \mathrm{Hg}$, iii) With significant proteinuria $(2+$ or more by dipstick method) ; and inclusion criteria for group II were, i) Normal pregnant woman of gestational age between 24-40weeks (age 18-35yrs), ii) Diastolic blood pressure $<90 \mathrm{~mm} \mathrm{Hg}$ and Systolic blood pressure $<140 \mathrm{~mm} \mathrm{Hg}$, iii) without any medical or obstetric complications. Exclusion criteria were pregnancy with complications Diabetes 
Mellitus, Renal sufficiency, urinary Tract infection, Liver Disease, Essential Hypertension, Heartldisease, Thyroid Disease, and Renal Stone. Pre-eclampsia was defined as 1) pregnant patient with Diastolic Blood pressure $\geq 90 \mathrm{~mm} \mathrm{Hg}$ and Systolic blood pressure $\geq$ $140 \mathrm{~mm}$ of $\mathrm{Hg}$, 2) Significant proteinuria: $2+$ pr more by Dipstick test of two random clean catch urine specimen collected at 04 hours interval, 1 st in the morning and 2nd 04 hours later. Variables utilized were age (years), gestational age (weeks), Parity, gravidity, socio-economic condition, previous history of pre-eclampsia, history of pre-eclampsia in the family, occupation, pulse, systolic blood pressure, diastolic blood pressure, oedema, proteinuria, uterine height, foetal movement, foetal heart rate, height, weight, basal metabolic index, serum calcium, serum creatinine, serum uric acid, urinary calcium, urinary creatinine, urinary protein, urinary calcium/creatinine ratio. After patient selection clinical examination was done and clinical data were collected and recorded according to data sheet. Questionnaires and checklist were also utilized. A morning random urine sample of all the patients was collected and proteinuria detected by dipstick method. After all aseptic precaution $05 \mathrm{ml}$ of venous blood was taken and sent to laboratory to determine serum calcium, creatinine \& uric acid. Urine was sent to the laboratory to determine calcium, creatinine, protein and calcium/creatinine ratio. A second urine sample was collected after $04 \mathrm{hrs}$ to detect proteinuria again by dipstick method. Statistical analysis by SPSS version 12.0. Chi-square test, ' $t$ ' test, Fisher's Exact test and correlation (r) tests were done. Level of significance was expressed as $\mathrm{P}$ value. $\mathrm{P}$ value $<0.05$ was considered as significant.

\section{Results}

Regarding the demographic variables, mean age \pm SD of the preeclampsia and normal pregnant group were
$27.57 \pm 4.88 \mathrm{yrs}$ and $26.22 \pm 3.30 \mathrm{yrs}$ respectively. There was no statistically significant difference $(\mathrm{p}=0.05)$. but in case of gestational age, mean \pm sd value were $30.96 \pm 3.50$ and $28.49 \pm 4.29$ weeks respectively and differed significantly $(\mathrm{p}<0.001)$. When age group was evaluated maximum no of preeclampsia pts were observed in age groups below 30 yrs $(65.32 \%)$ and below 35 weeks of gestational age $(89.33 \%)$. No significant difference was observed regarding occupation and socioeconomic status. Comparison of gravidity between the two groups revealed no significant difference $(\chi 2=.718, \quad \mathrm{p}>0.05)$. Primigravidity was noted in $30(40 \%)$ cases of preeclampsia and $25(33.33 \%)$ cases of normal pregnant patients. Regarding parity $44 \%$ patients of preeclampsia and $37 \%$ normal pregnant were nullipara; but $36 \%$ of both groups were primipara (Table 1 ).

No significant difference was observed in respect to pulse rate $(p>0.05)$. but systolic $(151 \pm 9.01$ vs $106 \pm$ 9.5, $\mathrm{p}<0.001)$ and diatolic blood pressure $(98.27 \pm 6.80$ vs $69 \pm 7.4, p<0.001)$ showed a great variation between the preeclampsia and normal pregnant groups. Distribution of different grades of oedema revealed highly significant difference between two groups $(\chi$ $2=125.69, \mathrm{p}<0.001)$. grade II oedema was the highest $(51.7 \%)$ in preeclampsia patients. Grade III oedema seen in $11 \%$ of preeclampsia patients. Mean heights of the two groups were identical but highly significant difference was noted between preeclampsia and normal pregnant group in case of weight $(63.13 \pm 3.26$ vs $52.96 \pm 5.29, \mathrm{p}<0.001)$ and body mass index $(27.43 \pm$ 1.54 vs $23.57 \pm 1.54, p<0.001)$. Uterine height did not show any variation between preeclampsia and normal pregnant patients $(29.42 \pm 3.20$ vs $28.37 \pm 4.37$, $\mathrm{p}>0.05$ ). similarly foetal heart rate and foetal movement did not show statistical significant difference. History of past preeclampsia was observed in $12 \%(9 / 75)$ of preeclampsia patients and $2.7 \%(2 / 75)$

Table 1: Table showing demographic variables

\begin{tabular}{llcccc}
\hline Variables & & \multicolumn{2}{c}{ Cases } & $\begin{array}{c}\text { Chi-square } \\
\text { Value }\end{array}$ & P \\
\cline { 3 - 5 } Gravidity & Primi & $30(40 \%)$ & $25(33.33 \%)$ & & \\
Occupational status & Multi & $45(60 \%)$ & $50(66.7 \%)$ & 0.718 & 0.49 \\
& HW & 71 & 66 & & \\
\multirow{5}{*}{ Socio-economic Condition } & Job & 3 & 4 & 2.86 & 0.24 \\
& Business & 1 & 5 & & \\
P/H/O & Poor & 16 & 18 & 1.75 & 0.50 \\
pre-eclampsia & Middle & 57 & 57 & & \\
\hline
\end{tabular}


Table 2: Physical and Clinical Variables

\begin{tabular}{|c|c|c|c|c|}
\hline \multirow[t]{2}{*}{ Variables } & \multicolumn{2}{|c|}{ Mean \pm SD } & \multirow[t]{2}{*}{ Test Value } & \multirow[t]{2}{*}{ Pvalue } \\
\hline & $\operatorname{PE}(n=75)$ & Normal(n=75) & & \\
\hline$\overline{\text { Age }}$ & $27.57 \pm 4.88$ & $26.22 \pm 3.30$ & $1.97(\mathrm{t})$ & 0.05 \\
\hline Mean Gestational age & $30.96 \pm 3.50$ & $28.49 \pm 4.29$ & $3.05(\mathrm{t})$ & $* 0.0001$ \\
\hline Pulse Rate & $84.48 \pm 6.99$ & $84.51 \pm 4.50$ & $0.2(\mathrm{t})$ & 0.97 \\
\hline Systolic Blood Pressure & $151.67 \pm 9.01$ & $106.00 \pm 9.58$ & $30.05(\mathrm{t})$ & $* 0.0001$ \\
\hline Diastolic Blood Pressure & $98.27 \pm 6.80$ & $69.60 \pm 7.43$ & $24.63(\mathrm{t})$ & $* 0.0001$ \\
\hline \multirow[t]{3}{*}{ Oedema(Grade) } & $23(\mathrm{Gr} I)$ & $7(\mathrm{Gr} \mathrm{I})$ & & \\
\hline & 38(Gr II) & $0(\mathrm{GrII})$ & $125.69(\chi 2)$ & $* 0.0001$ \\
\hline & 8(Gr III) & $0($ GrIII) & & \\
\hline Height & $151.78 \pm 3.55$ & $150.12 \pm 4.16$ & $2.63(\mathrm{t})$ & $* 0.009$ \\
\hline Weight & $63.13 \pm 3.26$ & $52.96 \pm 5.29$ & $14.16(t)$ & $* 0.0001$ \\
\hline BMI & $27.43 \pm 1.54$ & $23.57 \pm 1.90$ & $13.63(\mathrm{t})$ & $* 0.0001$ \\
\hline Uterine Height & $137.73 \pm 3.24$ & $137.82 \pm 3.12$ & $.17(\mathrm{t})$ & 0.095 \\
\hline Foetal Heart Rate & $29.42 \pm 3.20$ & $28.37 \pm 4.37$ & $1.68(\mathrm{t})$ & 0.85 \\
\hline
\end{tabular}

*Significant

of normal pregnancy $(\mathrm{p}>0.05)$. History of preeclampsia in family was not observed in any subject of the two group (Table 2).

Serum calcium concentration of preeclampsia group $(8.28 \pm .42)$ and normal pregnancy $(8.42 \pm .39)$ varied significantly $(\mathrm{p}<0.05)$. On the other hand serum creatinine concentration didn't show significant difference $(1.13 \pm .27 \quad$ vs $1.05 \pm \quad .21, \quad \mathrm{p}>0.05)$. Significantly higher serum Uric acid concentration was observed in preeclampsia patients $(6.76 \pm 1.99$ vs $3.86 \pm$ $.75, \mathrm{p}<0.01)$. Regarding urinary biochemical in the present study, we estimated spot urinary calcium concentration $(\mathrm{mg} / 100 \mathrm{ml})$, spot urinary creatinine concentration $(\mathrm{mg} / 100 \mathrm{ml})$ and spot urinary protein concentration $(\mathrm{mg} / 100 \mathrm{ml})$. From these results we calculated spot urinary calcium/creatinine (mg per 100 $\mathrm{ml} / \mathrm{mg}$ per $100 \mathrm{ml}$ ) ratio. We found that women with preeclampsia didn't differ significantly from normal pregnant patients in respect of urinary creatinine concentration $(60.45 \pm 32.13$ vs $53.11 \pm 20.17, \mathrm{p}>0.05)$. But the results were significant in case of spot urinary calcium and protein concentration. Women with preeclampsia showed reduced excretion of calcium in comparison to normal pregnant women when spot urinary calcium concentration was evaluated (3.45 \pm 2.61 vs $7.39 \pm 2.80, \mathrm{p}<0.001)$. In the present study we compared spot urinary calcium to creatinine ratio of normal pregnant woman and pre-eclampsia and the result was highly significant. The ratio reduced in preeclampsia patient in comparison to normal pregnant $(.06 \pm .05$ vs $.13 \pm .06, \mathrm{p}<0.001)$. A correlation analysis was done between spot urinary calcium/creatinine ratio and other variables. It correlated significantly and positively with spot urinary calcium concentration $(\mathrm{r}=0.64, \mathrm{p}<0.001)$ and correlated negatively with spot urinary protein concentration $(\mathrm{r}=0.28, \mathrm{p}<0.01)$ (Table $3)$.

Table 3: Biochemical variables among the Study Population

\begin{tabular}{|c|c|c|c|c|}
\hline \multirow[t]{2}{*}{ Variables } & \multicolumn{2}{|c|}{ Mean \pm sd } & \multirow{2}{*}{$\begin{array}{l}\text { 't' Test } \\
\text { Value }\end{array}$} & \multirow[t]{2}{*}{ Pvalue } \\
\hline & $\operatorname{PE}(n=75)$ & $\operatorname{Normal}(n=75)$ & & \\
\hline $\begin{array}{l}\text { Serum } \\
\text { Calcium }\end{array}$ & $8.28 \pm .42$ & $8.42 \pm .39$ & 2.08 & $* 0.039$ \\
\hline $\begin{array}{l}\text { Serum } \\
\text { Creatinine }\end{array}$ & $1.13 \pm .27$ & $1.05 \pm .21$ & 1.92 & 0.056 \\
\hline $\begin{array}{l}\text { Serum } \\
\text { Uric Acid }\end{array}$ & $6.76 \pm 1.99$ & $3.87 \pm .75$ & 11.74 & $* * 0.0001$ \\
\hline $\begin{array}{l}\text { Urinary } \\
\text { Calcium }\end{array}$ & $3.45 \pm 2.61$ & $7.39 \pm 2.80$ & 8.89 & $* 0.0001$ \\
\hline $\begin{array}{l}\text { Urinary } \\
\text { Creatinine }\end{array}$ & $60.45 \pm 32.13$ & $53.11 \pm 20.17$ & 1.67 & 0.09 \\
\hline $\begin{array}{l}\text { Urinary } \\
\text { Protein }\end{array}$ & $302.82 \pm 16.28$ & $246.31 \pm 3.10$ & 10.07 & $* * 0.0001$ \\
\hline $\begin{array}{l}\text { Urinary } \\
\mathrm{Ca} / \mathrm{Cr}\end{array}$ & $.06 \pm 0.05$ & $0.13 \pm 0.06$ & 7.31 & $* 0.0001$ \\
\hline
\end{tabular}

*Significant

\section{Discussion}

This cross sectional comparative study was conducted in the department of obstetrics and Gynaecology, Dhaka Medical College Hospital including both outdoor and indoor. During the two years of study period total 150 patients were enrolled and divided into two groups; preeclampsia and normal pregnancy, each comprising of 75 subjects.

Regarding the demographic variables, mean age \pm SD of the preeclampsia and normal pregnant group were $27.57 \pm 4.88$ yrs and $26.22 \pm 3.30$ yrs respectively. There was no statistically significant difference $(\mathrm{p}=0.05)$. But 
in case of gestational age, mean $\pm \mathrm{SD}$ value were $30.96 \pm 3.50$ and $28.49 \pm 4.29$ weeks respectively and differed significantly $(p<0.001)$. When age group was evaluated maximum no of preeclampsia pts were observed in age groups below 30 years $(65.32 \%)$ and below 35 weeks of gestational age $(89.33 \%)$. No significant difference was observed regarding occupation and socioeconomic status. Comparison of gravidity between the two groups revealed no significant difference $\left(\chi^{2}=.718, \mathrm{p}>0.05\right)$. Primigravidity was noted in $30(40 \%)$ cases of preeclampsia and $25(33.33 \%)$ cases of normal pregnant patients. These results correlate well with the study outcome by Qublan et $\mathrm{al}^{9}$ and Soudan et $\mathrm{al}^{22}$. Regarding parity $44 \%$ patients of preeclampsia and $37 \%$ normal pregnant were nullipara; but $36 \%$ of both groups were primipara.

Regarding clinical variables no significant difference was observed in respect to pulse rate $(\mathrm{p}>0.05)$. But systolic $(151 \pm 9.01$ vs $106 \pm 9.5, \mathrm{p}<0.001)$ and diastolic blood pressure $(98.27 \pm 6.80$ vs $69 \pm 7.4, \mathrm{p}<0.001)$ showed a great variation between the preeclampsia and normal pregnant groups. Distribution of different grades of oedema revealed highly significant difference between two groups $\left(\chi^{2}=125.69, \mathrm{p}<0.001\right)$. Grade II oedema was the highest $(51.7 \%)$ in preeclampsia patients. Grade III oedema seen in $11 \%$ of preeclampsia patients. Mean heights of the two groups were identical but highly significant difference was noted between preeclampsia and normal pregnant group in case of weight $(63.13 \pm 3.26$ vs $52.96 \pm$ $5.29, \mathrm{p}<0.001)$ and body mass index $(27.43 \pm 1.54$ vs $23.57 \pm 1.54, \mathrm{p}<0.001)$. Uterine height did not show any variation between preeclampsia and normal pregnant patients $(29.42 \pm 3.20$ vs $28.37 \pm 4.37, \mathrm{p}>0.05)$. Similarly foetal heart rate and foetal movement did not show statistical difference. History of past preeclampsia was observed in $12 \%(9 / 75)$ of preeclampsia patients and $2.7 \%(2 / 75)$ of normal pregnancy $(p>0.05)$. History of preeclampsia in family was not observed in any subject of the two groups.

Biochemical variables: Serum calcium concentration of preeclampsia group (8.28 \pm .42$)$ and normal pregnancy $(8.42 \pm .39)$ varied significantly $(\mathrm{p}<0.05)$. On the other hand serum creatinine concentration didn't show significant difference $(1.13 \pm .27$ vs $1.05 \pm .21$, $\mathrm{p}>0.05$ ). Studies of Saudan et $\mathrm{al}^{22}$ supported our results of serum calcium but not that of serum creatinine. This variation in serum creatinine concentration from other studies is probably due to the exclusion criteria in the present study, patients of preeclampsia with complications (for example renal failure) were excluded from the study. Significantly higher serum
Uric acid concentration was observed in preeclampsia patients $(6.76 \pm 1.99$ vs $3.86 \pm .75, \mathrm{p}<0.01)$. Previous Research works by Saudan et $\mathrm{al}^{22}$ and Qublan et $\mathrm{al}^{9}$ had similar results indicating possibilities of serum uric acid to be considered as an important factor for preeclampsia.

Regarding urinary biochemical in the present study we estimated spot urinary calcium concentration $(\mathrm{mg} / 100 \mathrm{ml})$, spot urinary creatinine concentration $(\mathrm{mg} / 100 \mathrm{ml})$ and spot urinary protein concentration $(\mathrm{mg} / 100 \mathrm{ml})$. From these results we calculated spot urinary calcium/creatinine $(\mathrm{mg}$ per $100 \mathrm{ml} / \mathrm{mg}$ per $100 \mathrm{ml}$ ) ratio. We found that women with preeclampsia didn't differ significantly from normal pregnant patients in respect of urinary creatinine concentration $(60.45 \pm 32.13$ vs $53.11 \pm 20.17, \mathrm{p}>0.05)$. But the results were significant in case of spot urinary calcium and protein concentration. Women with preeclampsia showed reduced excretion of calcium in comparison to normal pregnant women when spot urinary calcium concentration was evaluated $(3.45 \pm 2.61$ vs $7.39 \pm$ $2.80, \mathrm{p}<0.001)$. This is in accordance with the observations made by previous authors. Taufield et $\mathrm{al}^{27}$ from the study of 40 women in third trimester, were the first to conclude that pre-eclampsia is associated with hypocalciurea, probably due to increased tubular reabsorption of calcium and decrease in glomerular filtration rate. Huikeshoven and Zuiderhoudt ${ }^{16}$ also studied urinary calcium excretion in 41 women and found a significant decrease. Sanches-Ramos et $\mathrm{al}^{31}$ confirmed previous finding of altered urinary calcium excretion in pregnant woman with pre-eclampsia. Vural et $\mathrm{al}^{32}$ conducted a case control study with 59 patients and concluded that hypocalciuria may be an important feature of pre-eclampsia. Malas et $\mathrm{al}^{28}$, Hwang et $\mathrm{al}^{33}$ and Bilgin et $\mathrm{a}^{25}$ from their studies concluded that hypocalciuria is an important feature of pre-eclampsia and 24 hrs urinary calcium excretion or calcium/creatinine ratio in random urine samples is a reliable index of pre-eclampsia. Results of the present study are consistent with previous ones.

In the present study we compared spot urinary calcium to creatinine ratio of normal pregnant woman and pre-eclampsia and the result was highly significant. The ratio reduced in preeclampsia patient in comparison to normal pregnant $(.06 \pm .05$ vs $.13 \pm .06$, $\mathrm{p}<0.001)$. These results correlate very well with several previous studies. Kazerooni et all conducted a similar study with 102 patients and result was in favor of significantly lowered calcium/creatinine ratio in preeclampsia. Similar were the outcome of research work by Szmidt-Adjide et $\mathrm{a}^{13}$ who also revealed results in favor of the present proposition in a case 
control study consisting of 47 preeclampsia women and 50 controls. Rodriguez et $\mathrm{al}^{19}$ suggested that calcium/creatinine ratio may be useful in predicting preeclampsia and evaluated the calcium creatinine ratio in 88 normotensive pregnant women. The patients were between 24-34 weeks gestation and first morning urinary samples were tested. Similar findings by Ritz et $\mathrm{al}^{26}$ demonstrated a predictive nature of spot urine calcium/ creatinine ratio in preeclampsia. Previous studies ${ }^{29}$ showed that there is a good correlation between 24 hours urinary calcium excretion $(\mathrm{mg} / 24 \mathrm{hrs})$ and calcium to creatinine ratio of a single voided morning urine sample $(\mathrm{mg} / \mathrm{dl})$. Gokce et $\mathrm{al}^{30}$ also demonstrated strong correlation between spot urine calcium/creatinine ratio and 24 hours urinary calcium estimation in adults and concluded that estimation of calcium/creatinine in a single voided random urine specimen is a simple, cost effective and reliable method of estimating total urinary calcium excretion. This observation has also been made by Huikeshoven and Zuijderhovdt ${ }^{16}$ and they also showed that this correlation was better than the one between the calcium concentration of a single voided sample and 24 hour calcium concentration. From these result we can come to the conclusion that spot urinary calcium creatinine ratio is a very useful indicator of hypocalciuria. It is very important to point out that hypocalciuria in observed in many studies with preeclampsia patients s $^{27,30-32}$. Thus spot urinary calcium/creatinine ratio can be considered to be a very important and valuable predictor in the care and study of pregnant patients with preeclampsia. We also compared spot urinary protein of both groups which show highly significant variation.

A correlation analysis was done between spot urinary calcium/creatinine ratio and other variables. It correlated significantly and positively with spot urinary calcium concentration $(\mathrm{r}=0.64, \mathrm{p}<0.001)$ and correlated negatively with spot urinary protein concentration $(r=0.28, p<0.01)$.

\section{Conclusion}

The results of the present and several other studies reveal that reduced urinary calcium excretion or hypocalciuria may be an important feature of preeclampsia. It requires $24 \mathrm{hrs}$ urine calcium estimation which is cumbersome, time consuming, costly and non compliant. But it has been observed that spot urine calcium/creatinine ratio decreases in preeclampsia and significantly correlate with urinary calcium excretion. So spot urinary calcium to creatinine ratio measurement can be a very good alternative to hypocalciuria measurement. Spot urinary calcium to creatinine ratio can be a good predictor of preeclampsia.

\section{References}

1. Kazerooni T, Hamze-Nezadi S. Calcium to creatinine ratio in a spot sample of urine for early prediction of pre-eclampsia. Int J Gynaecol Obstet 2003;80(3):279-83.

2. Robson SC. Hypertension and renal disease in pregnancy. In: Edmonds DK editor. Dewhurts Text Book of Obstetrics and Gynaecology for Post-Graduates. 6th ed. London: Black well Science Publication; 1999: p.166-185

3. Khatoon MS. Clinical profile and management of preeclampsia in SSMCH and MF, Dhaka, [Dissertation], Bangladesh College of Physicians and Surgeons, 1992

4. Hladunewich M, Karumanchi SA, Lafayette R. Patho-physiology of clinical manifestations of preeclampsia. Cli J Am Soc Nephrol 2007;2:543-549.

5. Friedman SA, Schiff E, Emeis JJ, et al. Biochemical corroboration of endothelial involvement in severe preeclampsia. Am J Obstet Gynecol. 1996;172: 202-3

6. Jaramillo PL, Casas JP, Serrano N. Preeclampsia: From epidemiological observation to molecular mechanism. Braz J Med Biol Res 2001;34(10):1227-35

7. Solomon CG, Seely EW. Preeclampsia-Searching for the cause. N Eng J Med. 2004; 350(7):641-2

8. Moran P, Baylis PH, Lindheimer MD. Davidson JM. Glomerular ultra filtration in normal and pre-eclamptic pregnancy. J Am Soc nephro. 2003;14(3): 648-52

9. Qublan HS, Ammarin V, Bataineh O, et al. Lactic dehydrogenase as a biochemical marker of adverse pregnancy outcome in severe Preeclampsia. Med Sci Moni 2005;11(8):393-7

10. Magann EF, Martin JNJ. The Laboratory Evaluation of Hypertensive Gravidas. Obstetrical Gynecological Survey. 1995;50(2):138-145

11. Kovacs CS. Calcium and Bone Metabolism in Pregnancy and Lactation. J Clinical Endocrinology Metabolism 2001;86(6):2344-2348.

12. Ingec M, Nazik H, Kadanali S. Urinary calcium excretion in severe preeclampsia and eclampsia. Clin Chem Lab Med 2006;44(1): 511-3

13. Szmidt-Adjide V, Vendittelli F, David S, Bredent-Bangou J, Janky E. Calciuria and preeclampsia: A Case-control study. Eur J Obstet Gynecol Reprod Bio 2006;125(2):193-8

14. Ramos JGL, Martins-Costa SH, Kesseler JB, Costa CA, Barros E. Calciuria and preeclampsia. Braz J Med Biol Res 1998;31(4):519-22.

15. Suarez VR, Trelles JG, Miyahira JM. Urinary Calcium in asymptomatic primigravidas who later developed preeclampsia. Obstetrics Gynecology 1996; 87: 79-82

16. Huikeshoven FJM, Zuijderhoudt FMJ. Hypocalciuria in hypertensive disorders of pregnancy and how to measure it? Eu J Obs Gynecol 1990;36(1-2):81-85

17. Ozcan T, Kaleli B, Ozeren m, Turan C, Zorlu G. Urinary calcium to creatinine ratio for predicting preeclampsia. Am J Perinato. 1995;12(5): 349-51

18. Srivvastava KJ, Mishra RK, Sharma N, Pandey ON, Gupta S. Role of urinary calcium Creatinine ratio in prediction of pregnancy induced hypertension. The Journal of Obstetrics and Gynecology of India. 2002; 52(2): 39-42

19. Rodriguez MH, Masaki DI, Mestman J et al. Calcium/Creatinine ratio and microalbuminuria in the prediction of preeclampsia. Am J Obstet Gynecol 1988;159(6): 1452-5

20. Stars GV, Virgilli I, Croes Al, Garcia HK, Lucia C. Preeclampsia-eclampsia: Urinary calcium like prediction marker. Rev Obstet 
Gynecol Venez 2006;66(1):72-79

21. Izumi A, Minarami $\mathrm{H}$, Kuwata $\mathrm{T}$ et al. Calcium to creatinine ratio in spot urine sample in early pregnancy and relation to development of preeclampsia. Metabolism 1997;46:1107-8

22. Saudan PJ, Shaw L, Brown MA. Urinary calcium/creatinine ratio as a predictor of preeclampsia. Am J Hypertens 1998;11(7):839-43

23. Raniolo E, Philipon G. Prediction of pregnancy-induced hypertension by means of the urinary calcium:creatinine ratio. Med $\mathrm{J}$ Au 1993;158(2): 98-100

24. Taka M, Hirota Y, Makato MY, Miyagawa Y. Toxemia of pregnancy in low calcium urine disease, Hypocalciuria in women with Preeclampsia. Japanese Journal of Obstetrics and Women of Science and Acta Obstetrica et Gynecologica Japonic. 2003;44(1):28-32

25. Bilgin T, Kutlu O, Kimya Y, Kucukkomurcu S, Uncu G. Urine Calcium excretion in preeclampsia. Turkiye Klinikeiri J Gynecol Obst. 2000;10: 29-32

26. Rizk DEE, Agarwal M, Patha GY, Obineche EN. Predicting proteinuria in Hypertensive Pregnancies with urinary protein-creatinine and calcium-creatinine ratio. Journal of Perinatology 2007; 27: $272-277$
27. Taufield PA, Alse KL, Resnik LM, Druzin ML, Gertner JM. Hypocalciuria in preeclampsia. Tour J Med Sci 1987;316(12):715-718

28. Malas NO, Shurideh ZM. Does serum calcium in preeclampsia and Normal pregnancy differ? Saudi Medical Journal 2001;21:43-48

29. Yasmin N et al. Study of Urinary Calcium Excretion in preeclampsia. J Dhaka med col. October 2001; 10: 86-90.

30. Gokce C, Gokce O, Baydinc C, Ijhan N, Alasehrli E, Ozkucuk $\mathrm{F}$, et al. Use of random urine sample to estimate total urinary calcium and phosphate excretion. Arch intern Med. 1991;151(8):1587-1588.

31. Sanchez-Ramos L, Jones DC, Cullen MT. Urinary Calcium as an early marker for preeclampsia. Obstetrics Gynecology 1991;77(5): 685-688.

32. Vural P, Akgul C, Canbaz M. Calcium and Phosphate Excretion in Preeclampsia. Tour J Med Sci. March 2000;30(1): 39-42.

33. Hwang, HK, Moon TI, Lee YH \& Hwang. Study of Early Development of Hypocalciuria in Patients of Preeclampsia and its Diagnostic Strategy. Korean J Obstet Gynecol 1997;40(9): 1881-1886. 